\title{
Comparative Study on Antidiabetic Effects of Coenzyme Q10 and Quercetin on Streptozotocin-Induced Hyperglycemia in Rats
}

\author{
El-Sayed H. Bakr \\ Assistant professour at Nutrition and Food Science Department, Faculty of \\ Home Economics, Menofia University, Shebein El-Kom, Egypt.
}

\begin{abstract}
As estimated by Federation Diabetes Atlas, the number of diabetic patients will reach globally 592 million in 2035. Diabetes mellitus is a metabolic disorder characterized by hyperglycemia resulting from deficiency of insulin, its resistance or both. This investigation aimed to explore comparinor the antidiabetic effect of coenzyme Q10 and quercetin on streptozotocininduced hyperglycemia in rats. A sum of 24 adult male Albino rats weighing $200 \pm 5 \mathrm{~g}$ each were used and were divided into 4 groups $(\mathrm{n}=6$ rats). One group kept as ( $\mathrm{C}-\mathrm{ve})$ and fed on basal diet all over the experimental period (28 days), while the other groups were intraperitoneal injected with streptozotocin (STZ) at a dose of $40 \mathrm{mg} / \mathrm{kg}$ once a week for two weeks. One of the diabetic groups was fed basal diet only $(\mathrm{C}+\mathrm{ve})$ and the other two diabetic groups were fed on Coenzyme Q10 and Quercetin at a dose of $100 \mathrm{mg} / \mathrm{kg}$ body weight (b. wt.) each. At the end of the trial, rats were mercy sacrificed and the blood and organs were removed then serum glucose, insulin, TSH, LH, TC, TG, HDL, LDL, VLDL, T.P, Alb., T.B, AST, ALT, ALP, BUN, Creat., and uric acid were estimated. The results revealed that all hyperglycemic rats with orally administered Coenzyme Q10 and Quercetin at a dose of $100 \mathrm{mg} / \mathrm{kg} \mathrm{b}$. wt. each, showed significant increase in BWG, FI, FER and HDL, whereas significant decreases in serum glucose, insulin, TSH, LH, TC, TG, LDL, VLDL, T.P, Alb., T.B, AST, ALT, ALP, BUN, Creat., and uric acid recorded compared to control positive groups. Furthermore, Coenzyme Q10 induced higher enhancing of improvement rather than quercetin inspite that quercetin has natural healing properties as it is a natural flavonoid. In conclusion, Coenzyme Q10 and Quercetin have antidiabetic effects on streptozotocin-induced hyperglycemia in rats, indicating higher effect for CoQ10 in spite of singularity for quercetin as a natural flavonoid.
\end{abstract}

Key words: Coenzyme Q10, Quercetin, STZ, diabetic rats.

\section{Introduction}

As estimated by Federation Diabetes Atlas, the number of diabetic patients will reach globally 592 million in 2035 (IDF, 2013). Diabetes mellitus is a metabolic disorder characterized by hyperglycemia resulting from deficiency of insulin, its resistance or both. Chronic hyperglycemia can lead to 
severe damage and failure of many organs including liver, eyes, kidneys, heart, and blood vessels (ADA, 2014) and (Sreekutty and Mini, 2016). Diabetic type II patients are more likely to have cardiovascular complications associated with hyperglycemia such as heart disease, high blood pressure, stroke and nephropathy (WHO, 2016).

Coenzyme Q10 (CoQ10) is a fat-soluble compound and mainly synthesized by mitochondria in some body organs such as heart, liver, kidneys, pancreas, and muscles, where it is consumed in a large amount by the production of adinosine tri-phosphate (Acosta et al., 2016 and Crane, 2001). CoQ10 (also known as Ubiquinone) is a water-insoluble component found in nearly all cell membranes, and has multiple metabolic functions (Quinzii et al., 2007). It is a major component for the mitochondrial electron transport system (Crane, 2001 \& Littarru and Langsjoen 2007). Accordingly, exogenous coenzyme Q10 supplementation may improve oxidative stress induced by abnormalities in mitochondrial function, thus improving glycemic control in type II diabetic patients. (Alam and Rahman 2014).

Quercetin dihydrate (3, 3, 4, 5, 7-Penta-hydroxy flavone) is a flavonoid or more specifically a subclass called flavonols which are widely distributed in the plant kingdom. It is found in many foods such as onions, cilantro, sweet potatoes, broccoli, and kale. It is widely used particularly, as has been traditionally reported to fight many diseases such as obesity (Rayalam et al., 2008; Ahn et al., 2008), Anti-diabetes (Di Carlo et al., 1999; Vessal et al., 2003), anti-fertility (Formica and Regelson 1995), and anti-sclerotic (Salvamani et al., 2014 and Kleemann et al., 2011).

Quercetin can regulate and normalize lipoprotein levels in blood plasma through antioxidants, which prevent elevated the accumulation of cholesterol and oxidized lipids as well as hypercholesterolemia inhibition as a risk factor for diabetes mellitus (Fuhrman and Aviram, 2001).

Therefore, this investigation aimed to compare the antidiabetic effects of coenzyme Q10 and quercetin on streptozotocin-induced hyperglycemia in rats.

\section{Materials and Methods}

\section{a. Materials:}

1. Active ingredients: Active ingredients consisted of Coenzyme Q10 a syntheric compound which was purchased from Al-Nahdy pharmacy and quercetin, in the form of quercetin hydrate $\geq 95 \%$, which was purchaesd from Trust Company for Chemicals, Geddah, KSA.

2. Streptozotocin: Fine pure chemical, used for inducing diabetes in this study, was purchased from Trust Company for chemicals, Geddah, KSA..

3. Rats: Rats were obtained from animal house of Medical Biochemistry Department, Faculty of Medicine, Umm Al-Qura University, KSA. 
4. Basal diet: Basal diet consisted of casein $(12.5 \%)$, corn oil $(10 \%)$, choline chloride $(0.2 \%)$, vitamin mixture (1\%) (Campbell, 1963), cellulose $(5 \%)$, salt mixture (4\%) and corn starch (up to $100 \%$ ) according to the method described by Hegsted et al., (1941).

\section{b. Methods:}

\section{Active ingredient preparation:}

The first active ingredient, Coenzyme Q10, was dissolved in corn oil (Jerine et al., 2020), while the second active ingredient, quercetin, was dissolved in ethyl alcohol (Yang \& Kang 2018), in the ratio prescribed to be administered orally to rats by a dose of $100 \mathrm{mg} / \mathrm{kg} \mathrm{b}$. wt., each.

\section{Preparation of diabetic rats:}

Rats were received a dose of $40 \mathrm{mg} / \mathrm{kg}$ body weight via streptozotocin (STZ) injection. STZ was administered immediately after dissolving it in freshly prepared cold citrate buffer via intraperitoneal route used for Diabetes induction once a week for two weeks as the method prescribed by (Vessal $\boldsymbol{e t}$ al., 2003). Fasting blood glucose level greater than $160 \mathrm{mg} / \mathrm{dL}$ were considered as being diabetic.

\section{Experimental Design:}

Tweenty four male albino rats Sprague Dawley strain weighing $200 \pm 5 \mathrm{~g}$ each, were housed in the animal house of Medical Biochemistry Department, Faculty of Medicine, Umm Al-Qura University, Saudi Arabia. Rats were divided into two main groups, first group (6 rats) was fed on basal diet and left as negative control (Control -ve). The second group (18 rats) was inflicted by diabetes using the method prescribed by Vessal et al., (2003), then was divided into 3 groups ( $\mathrm{n}=6$ rats each) according to the following division:

1- Diabetic (control positive) group (+ve) which was fed on basal diet during the exepiremental period (28 days).

2- Diabetic rats fed on basal diet plus oral injection with Coenzyme Q10 at a dose of $100 \mathrm{mg} / \mathrm{kg}$ b.w., for 28 consecutive days as an experimental period.

3- Diabetic rats fed on basal diet plus oral injection with quercetin at a dose of $100 \mathrm{mg} / \mathrm{kg}$ b.w., for 28 consecutive days as an experimental period.

Rats body weights and food intake was recorded during the experimental period. At the end of the trial (28 days), rats were mercy sacrificed, blood sample were collected then centrifuged for 10 minutes at 4000 rotation per minute (r.p.m) for obtaining the serum. Liver and pancreas were removed and cleaned then weighed. 


\section{Biological evaluation:}

Biological evaluation was carried out by the estimation of body weight gain (BWG), food intake (FI) enaluation and feed efficiency ratio (FER) estimation according to Chapman et al., (1950) as follows: FER $=$ (Final weight - Initial weight) / Initial weight x100. Moreover, liver and pancreas weight were recorded for every rat individually then their relative to body weights were calculated.

\section{Biochemical analysis:}

Fasing glucose and insulin serum levels were determined according to the methods of Kaplan (1984) and Nakagawa et al., (1973), respectively. Thyroid stimulating hormone (TSH) was determined according to MatyjaszekMatuszek et al., (2013) and luteinizing hormone (LH) according to Soh and Aw (2019). Serum total cholesterol was determined according to Allain (1974) and serum triglycerides was according to Young and Pestaner (1975). Determination of HDLc was carried out according to the method of Friedewald (1972). The determinations of LDLc was carried out according to the method of Nauck et al., (2002) and very low density lipoprotein (VLDLc) calculated as triglycerides $/ 5$. Serum total protein, albumin and total bilirubin (T.B) were determined according to Gomal et al., (1949), Doumas et al., (1971) and Doumas et al., (1985), respectively. Colorimetric method was used to determine AST and ALT according to Reitman and Frankel (1957); moreover, determination of alkaline phosphates ALP activity was according to Haussament (1977). Blood urea nitrogen, creatinine and uric acid were determined according to (Pattn and Crouch, 1977), (Henry, 1974) and (Schultz, 1984), respectively.

\section{Statistical Analysis:}

Results were expressed as mean \pm standard error (SE) and statistically analyzed using Statistical Package for Social Sciences (SPSS, 2008). The double sample t-test was used to compare parameters between the positive control and diabetic rats with or without treatment groups. P-value less than 0.05 was considered statistically significant.

\section{Results and Discussion}

\section{Comparative between the antidiabetic effects of Coenzyme Q10} and Quercetin on FI, FER and BWG of streptozotocin-induced hyperglycemic rats:

Data listed in table (1) show the comparative antidiabetic effects of Coenzyme Q10 (CoQ10) and Quercetin at a dose of $100 \mathrm{mg} / \mathrm{kg}$ b. wt., each, on 
body weight gain (BWG), feed intake (FI) and feed efficiency ratio (FER) on streptozotocin-induced hyperglycemia rats.

Table (1): Comparison between the effects of CoQ10 and Quercetin on BWG, FI and FER of streptozotocin-induced hyperglycemic rats

\begin{tabular}{|l|c|c|c|}
\hline \multirow{2}{*}{ Groups } & \multicolumn{3}{|c|}{ Parameters } \\
\cline { 2 - 4 } & $\begin{array}{c}\text { BWG (g/28days) } \\
\text { Mean } \pm \text { SE }\end{array}$ & $\begin{array}{c}\text { FI (g/day) } \\
\text { Mean } \pm \text { SE }\end{array}$ & $\begin{array}{c}\text { FER } \\
\text { Mean } \pm \text { SE }\end{array}$ \\
\hline Control (-) & $39.00 \pm 0.12^{\mathrm{a}}$ & $9.73 \pm 0.07^{\mathrm{a}}$ & $0.143 \pm 0.003^{\mathrm{a}}$ \\
\hline Control (+) & $18.00 \pm 0.08^{\mathrm{d}}$ & $6.09 \pm 0.05^{\mathrm{d}}$ & $0.106 \pm 0.002^{\mathrm{d}}$ \\
\hline CoQ10 100 mg/kg b.w. & $31.00 \pm 0.09^{\mathrm{b}}$ & $8.33 \pm 0.02^{\mathrm{b}}$ & $0.133 \pm 0.004^{\mathrm{b}}$ \\
\hline Quercetin 100 mg/kg b.w. & $25.00 \pm 0.06^{\mathrm{c}}$ & $7.17 \pm 0.03^{\mathrm{c}}$ & $0.125 \pm 0.003^{\mathrm{c}}$ \\
\hline L.S.D & 3.11 & 0.93 & 0.005 \\
\hline
\end{tabular}

*Means with different letters $(a, b, c, d)$ in the same column differ significantly, using one-way ANOVA test, while there were no significant difference for those with similar letters $(\mathrm{P}<0.05)$.

It could be noticed that for hyperglycemic rats without treatment $(\mathrm{C}+\mathrm{ve}$ group) body weight gain (BWG), feed intake (FI) and feed efficiency ratio (FER) were $18.00 \pm 0.08 \mathrm{~g} / 28$ days, $6.09 \pm 0.05 \mathrm{~g} /$ day and $0.106 \pm 0.002$ compared to $39.00 \pm 0.12 \mathrm{~g} / 28$ days, $9.73 \pm 0.07 \mathrm{~g} /$ day and $0.143 \pm 0.005(\mathrm{C}-\mathrm{ve})$ for normal rats, $(\mathrm{P}<0.05)$. These results declared that there were significant decrease in body weight gain, feed intake and feed efficiency ratio for hyperglycemic rats without treatment as compared with normal rats. All diabetic rats that were orally injected with CoQ10 and quercetin at a dose of $100 \mathrm{mg} / \mathrm{kg} \mathrm{b}$. wt., each, showed significant increase in body weight gain, feed intake and feed efficiency ratio when compared to control positive group. All diabetic rats with orally administration by CoQ10 at a dose of $100 \mathrm{mg} / \mathrm{kg}$ b. wt., showed the highest significant increase in all previously mentioned parameters as compared to control positive groups.

These results are confirmed by the findings of Peter et al., (2019) who observed that rats with STZ-induced diabetes had a significant decrease ( $p$ $<0.05$ ) in body weights, which gradually decreased each week, furthermore, rats with diabetes that were treated with CoQ10 had an increase in body weight and the CoQ10 group only reached normal body weight.

Another study by Al-Attar (2010) suggested that Coenzyme Q10 has hypolipidemic effects in rats supplemented with a high cholesterol diet resulting in decreasing body weights in all treated rats.

Moreover, Jung et al., (2013) concluded that quercetin supplementation significantly reduced the body and liver weight in rats induced weight gain in the high-fat diet. 
2. Comparative between the antidiabetic effects of Coenzyme Q10 and Quercetin on relative liver and pancreas weights of streptozotocin-induced hyperglycemic rats:

Comparing the antidiabetic effects of Coenzyme Q10 (CoQ10) and Quercetin at a dose of $100 \mathrm{mg} / \mathrm{kg}$ b. wt. each group on relative liver and pancreas weights of streptozotocin-induced hyperglycemia rats are illustrated in table (2).

Table (2): Comparison between the effects of CoQ10 and Quercetin on relative liver and pancreas weights of streptozotocin-induced hyperglycemic rats

\begin{tabular}{|l|c|c|}
\hline \multirow{2}{*}{ Groups } & \multicolumn{2}{|c|}{ Parameters } \\
\cline { 2 - 3 } & $\begin{array}{c}\text { Liver }(\mathrm{g}) \\
\text { Mean } \pm \text { SE }\end{array}$ & $\begin{array}{c}\text { Pancreas (g) } \\
\text { Mean } \pm \text { SE }\end{array}$ \\
\hline Control (-) & $5.91 \pm 1.08^{\mathrm{a}}$ & $1.79 \pm 0.08^{\mathrm{a}}$ \\
\hline Control (+) & $3.18 \pm 0.92^{\mathrm{d}}$ & $0.89 \pm 0.02^{\mathrm{d}}$ \\
\hline CoQ10 100 mg/kg b.w. & $5.03 \pm 0.13^{\mathrm{b}}$ & $1.11 \pm 0.03^{\mathrm{b}}$ \\
\hline Quercetin $100 \mathrm{mg} / \mathrm{kg} \mathrm{b.w.}$ & $4.27 \pm 0.66^{\mathrm{c}}$ & $0.97 \pm 0.06^{\mathrm{c}}$ \\
\hline L.S.D & 0.05 & 0.02 \\
\hline
\end{tabular}

* Means with different letters $(\mathrm{a}, \mathrm{b}, \mathrm{c}, \mathrm{d})$ in the same column differ significantly, using one-way ANOVA test, while there were no significant difference for those with similar letters $(\mathrm{P}<0.05)$.

It could be noticed for control positive $(\mathrm{C}+\mathrm{ve})$ group that there was significant decrease in relative liver and pancreas weights $(\mathrm{P}<0.05)$ compared to control negative $(\mathrm{C}-\mathrm{ve})$ group. Moreover, there were significant increase in all diabetic rats with orally injection with $\mathrm{CoQ} 10$ and quercetin at a dose of $100 \mathrm{mg} / \mathrm{kg}$ b. wt. each, compared to control positive group and the highest increase was recorded in CoQ10 group.

Similar results were obtained by Martelli et al., (2020) who demonstrated that CoQ10 can withstand oxidation-reducing cycles, and its concentration is higher in organs of kidneys, heart and liver, which indicates a high metabolism rate and needs coenzyme Q10 as an adequate energy support system. In addition, Casuso et al., (2014) evaluated weight gain, caloric intake, and feed efficiency in exercise and sedentary mice with quercetin showing that relative weight of the liver is higher in the quercetin group when compared to the other studied groups.

3. Comparative between the antidiabetic effects of Coenzyme Q10 and Quercetin on serum fasting glucose and insulin of streptozotocin-induced hyperglycemic rats:

Comparative antidiabetic effects of Coenzyme Q10 (CoQ10) and quercetin at a dose of $100 \mathrm{mg} / \mathrm{kg} \mathrm{b}$. wt. each, on serum glucose and insulin on streptozotocin-induced hyperglycemia rats are recorded in table (3). 
Table (3): Comparison between the effects of CoQ10 and Quercetin on serum fasting glucose and insulin of streptozotocin-induced hyperglycemic rats

\begin{tabular}{|l|c|c|}
\hline \multirow{2}{*}{ Groups } & \multicolumn{2}{|c|}{ Parameters } \\
\cline { 2 - 3 } & $\begin{array}{c}\text { Glucose }(\mathrm{mg} / \mathrm{dL}) \\
\text { Mean } \pm \mathrm{SE}\end{array}$ & $\begin{array}{c}\text { Insulin }(\mathrm{mg} / \mathrm{dL}) \\
\text { Mean } \pm \mathrm{SE}\end{array}$ \\
\hline Control $(-)$ & $71.20 \pm 1.02^{\mathrm{d}}$ & $3.61 \pm 0.03^{\mathrm{d}}$ \\
\hline Control $(+)$ & $163.70 \pm 1.38^{\mathrm{a}}$ & $6.22 \pm 0.05^{\mathrm{a}}$ \\
\hline CoQ10 $100 \mathrm{mg} / \mathrm{kg}$ b.w. & $88.67 \pm 1.76^{\mathrm{c}}$ & $4.09 \pm 0.02^{\mathrm{c}}$ \\
\hline Quercetin $100 \mathrm{mg} / \mathrm{kg}$ b.w. & $115.13 \pm 2.03^{\mathrm{b}}$ & $5.11 \pm 0.03^{\mathrm{b}}$ \\
\hline L.S.D & 5.19 & 0.21 \\
\hline
\end{tabular}

* Means with different letters $(\mathrm{a}, \mathrm{b}, \mathrm{c}, \mathrm{d})$ in the same column differ significantly, using one-way ANOVA test, while there were no significant difference for those with similar letters $(\mathrm{P}<0.05)$.

It is clear from the table that serum glucose and insulin in hyperglycemic rats without treatment $(\mathrm{C}+\mathrm{ve}$ group) were $163.70 \pm 1.38$ and $6.22 \pm 0.05 \mathrm{mg} / \mathrm{dL}$, compared to $163.70 \pm 1.38$ and $3.61 \pm 0.03 \mathrm{mg} / \mathrm{dL}$, respectively, in normal rats $(\mathrm{C}$ -ve group) showing significant increase in control positve compared to control negative group.

Rats inflicted with hyperglycemia then orally injected with CoQ10 and Quercetin at a dose of $100 \mathrm{mg} / \mathrm{kg} \mathrm{b}$. wt., showed significant decrease in serum glucose and insulin serum levels when compared to control positive group. Also, hyperglycemic rats that were administered with CoQ10 at a dose of $100 \mathrm{mg} / \mathrm{kg} \mathrm{b}$. wt., showed the highest significant decreases in serum glucose and insulin as compared to Quercetin and control positive groups.

These findings were in agreement with that of Oyedemi et al., (2020) who showed that taking quercetin by mouth at a dose of 25 and $50 \mathrm{mg} / \mathrm{kg}$ for 28 days significantly decreased the levels of serum glucose, glycosylated hemoglobin $(\mathrm{Hb})$, and hepatic glycogen but with an enhanced plasma hemoglobin concentration..

Quercetin doses of 10-50 mg of body weight is able to normalize the serum glucose level, increase glycogen liver content and reduce serum cholesterol and low-density lipoprotein concentrations in diabetic rats (Nuraliev and Avezov, 1992).

Exposure of isolated rat langerhans islets to certain flavonoids including quercetin enhances insulin release by $44-70 \%$ via alteration in Ca2q fluxes and in cyclic nucleotide metabolism (Hii and Howell, 1985).

Quercetin produces an increase in activity of pancreatic islets resulting in insulin release in STZ-diabetic rats and induces more glucokinase enzyme in the liver (Vessal et al., 2003). 


\section{Comparative between the antidiabetic effects of Coenzyme Q10 and Quercetin on TSH and LH of streptozotocin-induced hyperglycemic rats:}

Table (4) display the comparative between antidiabetic effects of Coenzyme Q10 (CoQ10) and Quercetin at a dose of $100 \mathrm{mg} / \mathrm{kg} \mathrm{b}$. wt. each, on thyroid-stimulating hormone (TSH) and luteinizing hormone (LH) on streptozotocin-induced hyperglycemia rats.

Table (4): Comparison between the effects of CoQ10 and Quercetin on TSH and LH of streptozotocin-induced hyperglycemic rats

\begin{tabular}{|l|c|c|}
\hline \multirow{2}{*}{ Groups } & \multicolumn{2}{|c|}{ Parameters } \\
\cline { 2 - 3 } & $\begin{array}{c}\text { TSH }(\mathrm{mIU} / \mathrm{ml}) \\
\text { Mean } \pm \text { SE }\end{array}$ & $\begin{array}{c}\text { LH }(\mathrm{mIU} / \mathrm{ml}) \\
\text { Mean } \pm \text { SE }\end{array}$ \\
\hline Control (-) & $7.63 \pm 0.02^{\mathrm{a}}$ & $8.98 \pm 0.05^{\mathrm{a}}$ \\
\hline Control $(+)$ & $2.19 \pm 0.03^{\mathrm{d}}$ & $3.31 \pm 0.03^{\mathrm{d}}$ \\
\hline CoQ10 100 mg/kg b.w. & $4.09 \pm 0.01^{\mathrm{b}}$ & $4.59 \pm 0.03^{\mathrm{b}}$ \\
\hline Quercetin $100 \mathrm{mg} / \mathrm{kg}$ b.w. & $3.82 \pm 0.03^{\mathrm{c}}$ & $4.01 \pm 0.04^{\mathrm{c}}$ \\
\hline L.S.D & 0.13 & 0.28 \\
\hline
\end{tabular}

*Means with different letters $(a, b, c, d)$ in the same column differ significantly, using one-way ANOVA test, while there were no significant difference for those with similar letters $(\mathrm{P}<0.05)$.

It could be observed that there were significant decreases in thyroidstimulating hormone (TSH) and luteinizing hormone (LH) in hyperglycemic rats without treatment as compared to normal rats. Meanwhile, there were significant increases in these hormones in rats inflicted with hyperglycemia then orally injected with CoQ10 and Quercetin at a dose of $100 \mathrm{mg} / \mathrm{kg} \mathrm{b}$. wt., compared to control positive group.

Moreover, hyperglycemic rats which were administered with quercetin at a dose of $100 \mathrm{mg} / \mathrm{kg}$ b. wt., showed some improvement in both hormones, it could be noted the singularity for quercetin as a natural flavonoid than CoQ10 as a drug in adjusting these hormones in human body.

These findings were in agreement with that of Lee et al., (2012) who demonstrated that Coenzyme Q10 is an intracellular antioxidant that protects cells by blocking lipid peroxidation and replenishing other antioxidants that prevent oxidative damage caused by free radicals.

Moreover, Tušimová et al., (2017) concluded that the stimulatory effect was observed on FSH secretion at a higher dose of quercetin. Likewise, LH increased at concentrations of $100 \mathrm{mcg} / \mathrm{kg}$ and $1000 \mathrm{mcg} / \mathrm{kg}$, indicating the potential effect of quercetin on the secretion of selected pituitary hormones. 
5. Comparative between the antidiabetic effects of Coenzyme Q10 and Quercetin on TC and TG of streptozotocin-induced hyperglycemic rats:

Comparing antidiabetic effects of Coenzyme Q10 (CoQ10) and Quercetin at a dose of $100 \mathrm{mg} / \mathrm{kg} \mathrm{b}$. wt. each, on total cholesterol (TC) and triglyceride (TG) on streptozotocin-induced hyperglycemia rats are recorded in table (5).

Table (5): Comparison between the effects of CoQ10 and Quercetin on TC and TG of streptozotocin-induced hyperglycemic rats

\begin{tabular}{|l|c|c|}
\hline \multirow{2}{*}{ Groups } & \multicolumn{2}{|c|}{ Parameters } \\
\cline { 2 - 3 } & $\begin{array}{c}\text { TC }(\mathrm{mg} / \mathrm{dl}) \\
\text { Mean } \pm \text { SE }\end{array}$ & $\begin{array}{c}\text { TG }(\mathrm{mg} / \mathrm{dl}) \\
\text { Mean } \pm \text { SE }\end{array}$ \\
\hline Control $(-)$ & $51.98 \pm 1.02^{\mathrm{d}}$ & $25.20 \pm 1.25^{\mathrm{d}}$ \\
\hline Control $(+)$ & $73.90 \pm 1.38^{\mathrm{a}}$ & $45.95 \pm 0.59^{\mathrm{a}}$ \\
\hline CoQ10 $100 \mathrm{mg} / \mathrm{kg}$ b.w. & $55.27 \pm 1.06^{\mathrm{c}}$ & $31.40 \pm 1.71^{\mathrm{c}}$ \\
\hline Quercetin $100 \mathrm{mg} / \mathrm{kg}$ b.w. & $60.57 \pm 1.33^{\mathrm{b}}$ & $35.10 \pm 1.04^{\mathrm{b}}$ \\
\hline L.S.D & 2.19 & 1.98 \\
\hline
\end{tabular}

*Means with different letters (a, b, c, d) in the same column differ significantly, using one-way ANOVA test, while there were no significant difference for those with similar letters $(\mathrm{P}<0.05)$.

It could be noticed from the table that serum total cholesterol (TC) and triglyceride (TG) in normal rats (C -ve group) was significantly increased in (C $+\mathrm{ve})$ compared to $(\mathrm{C}-\mathrm{ve})$ which was $73.90 \pm 1.38,45.95 \pm 3.59,51.98 \pm 1.02$ and $25.20 \pm 1.25 \mathrm{mg} / \mathrm{dl}$, respectively. Hyperglycemic rats with orally fed by CoQ10 and Quercetin at a dose of $100 \mathrm{mg} / \mathrm{kg} \mathrm{b}$. wt. each, showed significant decrease in serm TC and TG as compared to control positive group. The highest significant decrease occurred in CoQ10 at a dose of $100 \mathrm{mg} / \mathrm{kg}$ b. wt., when compared to control positive group.

Quercetin-rich supplementation decreases serum levels of TC and increases serum concentrations of high density lipoprotein (HDL)-cholesterol (Igarashi and Ohmuma, 1995; Kamada et al., 2005; Gnoni et al., 2009; Lee et al., 2011). Furthermore, quercetin had significantly increased liver glucokinase activity and reduced serum cholesterol and triglycerides (TG) in diabetic animals (Hii and Howell 1985).

The mechanism of action of natural antioxidants including quercetin in reducing lipids occured due to inhibition of glycosylated lipoproteins, enzymes and proteins involved in the metabolism of fats and lipoproteins in the body (Carrier et al., 2014). Another explanatory mechanism is that CoQ10 increases fatty acid oxidation by activating the peroxisome-dependent protein kinaseactivated alpha receptor (Lee et al., 2012). 


\section{Comparative between the antidiabetic effects of Coenzyme Q10 and Quercetin on HDL, LDL and VLDL of streptozotocin-induced hyperglycemic rats:}

Data illustrated in table (6) show the comparative antidiabetic effects of Coenzyme Q10 (CoQ10) and Quercetin at a dose of $100 \mathrm{mg} / \mathrm{kg} \mathrm{b}$. wt. each, on high denisty lipoprotein (HDL), low denisty lipoprotein (LDL) and very low denisty lipoprotein (VLDL) on streptozotocin-induced hyperglycemia rats.

Table (6): Comparison between the effects of CoQ10 and Quercetin on HDL, LDL and VLDL of streptozotocin-induced hyperglycemic rats

\begin{tabular}{|l|c|c|c|}
\hline \multirow{2}{*}{ Groups } & \multicolumn{3}{|c|}{ Parameters } \\
\cline { 2 - 4 } & $\begin{array}{c}\text { HDL (mg/dl) } \\
\text { Mean } \pm \text { SE }\end{array}$ & $\begin{array}{c}\text { LDL }(\mathrm{mg} / \mathrm{dl}) \\
\text { Mean } \pm \text { SE }\end{array}$ & $\begin{array}{c}\text { VLDL } \\
(\mathrm{mg} / \mathrm{dl}) \\
\text { Mean } \pm \text { SE }\end{array}$ \\
\hline Control (-) & $27.91 \pm 0.87^{\mathrm{a}}$ & $19.03 \pm 0.33^{\mathrm{d}}$ & $5.04 \pm 0.05^{\mathrm{d}}$ \\
\hline Control (+) & $19.13 \pm 1.03^{\mathrm{d}}$ & $45.58 \pm 0.93^{\mathrm{a}}$ & $9.19 \pm 0.09^{\mathrm{a}}$ \\
\hline CoQ10 100 mg/kg b.w. & $23.29 \pm 0.94^{\mathrm{b}}$ & $25.70 \pm 0.17^{\mathrm{c}}$ & $6.28 \pm 0.04^{\mathrm{c}}$ \\
\hline Quercetin 100 mg/kg b.w. & $21.33 \pm 1.08^{\mathrm{c}}$ & $32.22 \pm 0.02^{\mathrm{b}}$ & $7.02 \pm 0.03^{\mathrm{b}}$ \\
\hline L.S.D & 1.09 & 3.39 & 0.71 \\
\hline
\end{tabular}

*Means with different letters $(\mathrm{a}, \mathrm{b}, \mathrm{c}, \mathrm{d})$ in the same column differ significantly, using one-way ANOVA test, while there were no significant difference for those with similar letters $(\mathrm{P}<0.05)$.

It is clear from table (6) that diabetic rats without treatment $(\mathrm{C}+\mathrm{ve})$ showed significant decrease in serum high denisty lipoprotein (HDL) but significant increase in low denisty lipoprotein (LDL) and very low denisty lipoprotein (VLDL) as compared to normal rats (C -ve). All treated groups showed significant increase in serum HDL and significant decrease in LDL and VLDL as compared to $(\mathrm{C}+\mathrm{ve})$ group. Hyperglycemic rats when orally administered with CoQ10 and Quercetin at the same dose of $100 \mathrm{mg} / \mathrm{kg}$ b.wt. each, showed reducing action in serum VLDL, indicating same effect when compared with control positive rats.

The results obtained agreed with Littarru, et al., (2011) and Song et al., (2017) who revealed that dietary supplementation with CoQ10 is recommended to improve clinical and metabolic disorders of cardiovascular disease regarding abnormal conditions such as aging and oxidative stress.

Coenzyme Q10 can provide protective enhancing for membrane phospholipids, mitochondrial membrane protein, and low-density lipoprotein (LDL-c) against oxidation (Lee et al., 2013). Moreover, quercetin is a powerful antioxidant with peroxyl radical cleaning activity (Ioku et al., 1995). It prevents low-density lipoprotein oxidation (Safari and Sheikh, 2003; Kerry and Abbey, 1997). Also, quercetin used in doses of $10-50 \mathrm{mg}$ of body weight, has 
ability in normalizing blood glucose level, increasing liver glycogen content and decreasing blood cholesterol and low-density lipoprotein concentration in diabetic rats (Nuraliev and Avezov, 1992).

\section{Comparative between the antidiabetic effects of Coenzyme Q10 and Quercetin on T.P, Alb, and T.B of streptozotocin-induced hyperglycemic rats:}

Data illustrated in table (7) show the comparative between the antidiabetic effects of Coenzyme Q10 (CoQ10) and Quercetin at a dose of $100 \mathrm{mg} / \mathrm{kg}$ b. wt. each, on serum total protein (T.P), albumin (Alb.), and total billirubin (T.B) on streptozotocin-induced hyperglycemia rats.

Table (7): Comparison between the effects of CoQ10 and Quercetin on T.P, Alb, and T.B of streptozotocin-induced hyperglycemic rats

\begin{tabular}{|l|c|c|c|}
\hline \multirow{2}{*}{ Groups } & \multicolumn{3}{|c|}{ Parameters } \\
\cline { 2 - 4 } & $\begin{array}{c}\text { T.P }(\mathrm{g} / \mathrm{dL}) \\
\text { Mean } \pm \text { SE }\end{array}$ & $\begin{array}{c}\text { Alb. }(\mathrm{g} / \mathrm{dL}) \\
\text { Mean } \pm \text { SE }\end{array}$ & $\begin{array}{c}\text { T.B }(\mathrm{g} / \mathrm{dL}) \\
\text { Mean } \pm \text { SE }\end{array}$ \\
\hline Control (-) & $9.70 \pm 0.03^{\mathrm{a}}$ & $4.79 \pm 0.03^{\mathrm{a}}$ & $0.15 \pm 0.01^{\mathrm{d}}$ \\
\hline Control (+) & $3.69 \pm 0.06^{\mathrm{d}}$ & $2.15 \pm 0.09^{\mathrm{d}}$ & $0.39 \pm 0.02^{\mathrm{a}}$ \\
\hline CoQ10 100 mg/kg b.w. & $7.20 \pm 0.05^{\mathrm{b}}$ & $3.08 \pm 0.02^{\mathrm{b}}$ & $0.29 \pm 0.02^{\mathrm{bc}}$ \\
\hline Quercetin $100 \mathrm{mg} / \mathrm{kg}$ b.w. & $6.03 \pm 0.06^{\mathrm{bc}}$ & $2.93 \pm 0.04^{\mathrm{bc}}$ & $0.31 \pm 0.01^{\mathrm{b}}$ \\
\hline L.S.D & 1.25 & 0.17 & 0.03 \\
\hline
\end{tabular}

*Means with different letters (a, b, c, d) in the same column differ significantly, using one-way ANOVA test, while there were no significant difference for those with similar letters $(\mathrm{P}<0.05)$.

It could be concluded from the table that serum total protein (T.P) and albumin (Alb.) mean values were significantly decreased but significantly increased in serum total billirubin (T.B) in $(\mathrm{C}+\mathrm{ve})$ compared to $(\mathrm{C}-\mathrm{ve})$. All tested groups showed significant increase in serum total protein (T.P) and albumin (Alb.) but significant decrease in serum total billirubin (T.B) as compared to $(\mathrm{C}+\mathrm{ve})$ group. Hyperglycemic rats with orally injection with CoQ10 and Quercetin at a dose of $100 \mathrm{mg} / \mathrm{kg}$ b. wt. each, showed nonsignificant differences neither in serum total protein (T.P) and albumin (Alb.) nor in serum total billirubin (T.B) compared with control positive group.

Coenzyme Q10 is responsible for energy production in body cells, moreover, it is responsible for ameliorating endothelial dysfunction as well as important for activating mitochondrial separation proteins (Turunen et al., 2004). 
A recent study declared that CoQ10 supplementation increases cyclic adenosine monophosphate production, reflicting that cAMP is an important intracellular second messenger that is involving in the regulation of AMPactivated protein kinase activity (Xu et al., 2017).

Furthermore, administration of quercetin with carbon tetra choloride reduced the levels of elevated liver enzymes, lipid peroxidation and elevated the levels of low antioxidants to reach normal range (Anim et al., 2020).

\section{Comparative between the antidiabetic effects of Coenzyme Q10 and Quercetin on AST, ALT and ALP of streptozotocin-induced hyperglycemic rats:}

Data presents in table (8) show the comparative beteen the antidiabetic effects of Coenzyme Q10 (CoQ10) and Quercetin at a dose of $100 \mathrm{mg} / \mathrm{kg} \mathrm{b}$. wt., each on liver enzymes (AST, ALT and ALP) of streptozotocin-induced hyperglycemic rats.

Table (8): Comparison between the effects of CoQ10 and Quercetin on AST, ALT and ALP of streptozotocin-induced hyperglycemic rats

\begin{tabular}{|l|c|c|c|}
\hline \multirow{2}{*}{ Groups } & \multicolumn{3}{|c|}{ Parameters } \\
\cline { 2 - 4 } & $\begin{array}{c}\text { AST (U/L) } \\
\text { Mean } \pm \text { SE }\end{array}$ & $\begin{array}{c}\text { ALT (U/L) } \\
\text { Mean } \pm \text { SE }\end{array}$ & $\begin{array}{c}\text { ALP (U/L) } \\
\text { Mean } \pm \text { SE }\end{array}$ \\
\hline Control (-) & $45.06 \pm 1.11^{\mathrm{d}}$ & $39.00 \pm 1.09^{\mathrm{d}}$ & $87.39 \pm 1.16^{\mathrm{d}}$ \\
\hline Control (+) & $83.01 \pm 2.32^{\mathrm{a}}$ & $95.00 \pm 2.36^{\mathrm{a}}$ & $126.55 \pm 2.96^{\mathrm{a}}$ \\
\hline CoQ10 100 mg/kg b.w. & $49.08 \pm 1.55^{\mathrm{c}}$ & $43.00 \pm 1.64^{\mathrm{c}}$ & $91.13 \pm 2.18^{\mathrm{c}}$ \\
\hline Quercetin $100 \mathrm{mg} / \mathrm{kg}$ b.w. & $53.12 \pm 2.33^{\mathrm{b}}$ & $58.00 \pm 2.01^{\mathrm{b}}$ & $99.87 \pm 1.08^{\mathrm{b}}$ \\
\hline L.S.D & 3.01 & 5.33 & 3.09 \\
\hline
\end{tabular}

*Means with different letters (a, b, c, d) in the same column differ significantly, using one-way ANOVA test, while there were no significant difference for those with similar letters $(\mathrm{P}<0.05)$.

Relating serum levels of liver enzymes (AST, ALT and ALP), values mentioned in table $(8)$, there were significantly increase $(\mathrm{P}<0.05)$ in control positive group compared to normal rats. All diabetic rats with orally injection with CoQ10 and Quercetin at a dose of $100 \mathrm{mg} / \mathrm{kg}$ b. wt. each, showed significant decreases in all liver enzymes (AST, ALT and ALP) compared to control positive group. Rats with orally administration with CoQ10 at a dose of $100 \mathrm{mg} / \mathrm{kg}$ b. wt., showed higher significant decrease in AST and ALT as compared to quercetin and control positive groups.

Coenzyme Q10 can protect the liver from oxidative damage due to improving antioxidant enzyme activities and reducing lipid peroxidation which consider a therapeutic intervention to protect liver injury (Samanta et al., 2021).

Furthermore, CoQ10 supplement might directly enhance antioxidant defense system via potentiating electron transport chain in liver mitochondria 
(Novoselova et al., 2009). Instead, modifying the expression of antioxidant enzymes in animals insists that dietary CoQ10 directly affects the expression of antioxidant enzymes in tissues (Sohal et al., 2006 and Novoselova et al., 2009).

Moreover, quercetin has the potential to mitigate high cholesterol diet induced lipid oxidative injury in rat livers due to antioxidant and increased nitrogen oxide bioavailability (Mariee et al., 2012).

\section{Comparative between the antidiabetic effects of Coenzyme Q10 and Quercetin on BUN, Creat., and U. Acid of streptozotocin- induced hyperglycemic rats:}

Data recorded in table (9) show the comparative antidiabetic effects of Coenzyme Q10 (CoQ10) and quercetin on blood urea nitrogen (BUN), creatinine (Creat.) and uric acid (U. Acid) of streptozotocin-induced hyperglycemic rats.

Table (9): Comparison between the effects of CoQ10 and Quercetin on BUN, Creat. and U. Acid of streptozotocin-induced hyperglycemic rats

\begin{tabular}{|l|c|c|c|}
\hline \multirow{2}{*}{ Groups } & \multicolumn{3}{|c|}{ Parameters } \\
\cline { 2 - 4 } & $\begin{array}{c}\text { BUN (mg/dl) } \\
\text { Mean } \pm \text { SE }\end{array}$ & $\begin{array}{c}\text { Creat. }(\mathrm{mg} / \mathrm{dl}) \\
\text { Mean } \pm \text { SE }\end{array}$ & $\begin{array}{c}\text { U. Acid (mg/dl) } \\
\text { Mean } \pm \text { SE }\end{array}$ \\
\hline Control (-) & $15.38 \pm 0.07 \mathrm{~d}$ & $0.71 \pm 0.02^{\mathrm{d}}$ & $1.53 \pm 0.03^{\mathrm{d}}$ \\
\hline Control $(+)$ & $38.90 \pm 0.23^{\mathrm{a}}$ & $0.98 \pm 0.03^{\mathrm{a}}$ & $3.01 \pm 0.04^{\mathrm{a}}$ \\
\hline CoQ10 100 mg/kg b.w. & $19.00 \pm 0.53^{\mathrm{bc}}$ & $0.79 \pm 0.02^{\mathrm{bc}}$ & $1.95 \pm 0.06^{\mathrm{c}}$ \\
\hline Quercetin $100 \mathrm{mg} / \mathrm{kg}$ b.w. & $21.43 \pm 0.12^{\mathrm{b}}$ & $0.81 \pm 0.01^{\mathrm{b}}$ & $2.02 \pm 0.02^{\mathrm{b}}$ \\
\hline L.S.D & 2.93 & 0.05 & 0.08 \\
\hline
\end{tabular}

*Means with different letters $(\mathrm{a}, \mathrm{b}, \mathrm{c}, \mathrm{d})$ in the same column differ significantly, using one-way ANOVA test, while there were no significant difference for those with similar letters $(\mathrm{P}<0.05)$.

Regarding kidney functions including blood urea nitrogen (BUN), creatinine (Creat.) and uric acid (U. Acid), there were significant increase $(\mathrm{P}<0.05)$ in control positive compared to control negative group. All diabetic rats with orally administered with coenzyme Q10 (CoQ10) and quercetin at a dose of $100 \mathrm{mg} / \mathrm{kg} \mathrm{b}$. wt. each, showed significant decrease in BUN, Creat., and U. Acid compared to control positive group. All diabetic rats with orally injection with CoQ10 and quercetin at a dose of $100 \mathrm{mg} / \mathrm{kg}$ b. wt., showed the same significant difference as compared to $(\mathrm{C}+\mathrm{ve})$ group.

There is an evidence that CoQ10 supplementation may improve renal function and reduce the need for dialysis in patients with CKD (Singh et al., 2000).

In a study of the antidiabetic effects of quercetin in streptozocin-induced diabetic rats by Vessal et al., (2003), results revealed that quercetin, a flavonoid with antioxidant properties, leads to regeneration of pancreatic islets and 
increases insulin secretion in diabetic rats induced by streptozocin; exerting its beneficial anti-diabetic effects.

Furthermore, Treatment with quercetin improves kidney functions and reduces oxidative stress factors and kidney inflammation (Yang et al., 2018).

\section{Conclusion}

This investigation concluded that Coenzyme Q10 and Quercetin have antidiabetic effects on streptozotocin-induced hyperglycemic rats, indicating higher effect for CoQ10 in spite of the singularity for quercetin as a natural flavonoid.

\section{References}

Acosta, M. J.; Vazquez, F. L.; Desbats, M. A, Zordan, R.; Trevisson, E. and Salviati, L. (2016): Coenzyme Q biosynthesis in health and disease. Biochim Biophys Acta.; 1857:1079-85.

ADA (American Diabetes Association) (2014): Diagnosis and classification of diabetes mellitus. Diabetes Care. 37 (Suppl 1):S81-S90.

Ahn, J.; Lee, H.; Kim, S.; Park, J. and Ha, T. (2008): The anti-obesity effect of quercetin is mediated by the AMPK and MAPK signaling pathways. Biochemistry and Biophysica Research Communication, 373: 545-9.

Alam, M. A. and Rahman, M. M. (2014): Mitochondrial dysfunction in obesity: potential benefit and mechanism of co-enzyme Q10 supplementation in metabolic syndrome. Journal of Diabetes \& Metabolic Disorders. 13 (1): 60.

Al-Attar, A. M. (2010): Hypolipidemic effects of coenzyme Q10 in experimentally induced hypercholesterolemic model in female rats. American Journal of Pharmacology and Toxicology, 5(1): 14-23. DOI: https://doi.org/10.3844/ajptsp.2010.14.23.

Allain, C.C. (1974): Cholesterol enzymatic colorimetric method. J. of Clin. Chem., (20): 470.

Anim, J. T.; Mushtaq, S. and Naz, L., (2020): Curative potential of quercetin against carbon tetracholoride-induced hepatotoxicity in wister rats. Journal of Animal and Plant Sciences, 30(6):1408-1414. DOI: 10.36899/JAPS.2020.6.0162.

Campbell, J.A. (1963). Methodology of protein evaluation. RAG Nutr. Document R.10 Led. 37. June Meeting, New York.

Carrier, B.; Wen, S.; Zigouras, S.; Browne, R. W.; Li, Z. and Patel, M. S, et al. (2014): Alpha-lipoic acid reduces LDL-particle number and PCSK9 concentrations in high-fat fed obese Zucker rats. PLoS One. 9(3): e90863,1-12. 
Casuso, R. A.; Martínez-López, E. J.; Hita-Contreras, F.; CamilettiMoirón, D. and Martínez-Amat, A. (2014): Quercetin effects on weight gain and caloric intake in exercised rats. J. of Biol., Sport. 31 (1): 63-7.

Chapman, D. G.; Gastilla, R. and Campbell, T. A. (1950): Evaluation of protein in food. I. A method for the determination of protein efficiency ratio. Can. J. Biochem. Physio., 1(37): 679-686.

Crane, F. L.(2001): Biochemical functions of coenzyme Q10. J Am Coll Nutr., 20:591-598. doi: 10.1080/07315724.2001.10719063.

Di Carlo, G.; Mascolo, N.; Izzo, A. A. and Capasso, F. (1999): Flavonoids: Old and newaspects of a class of natural therapeutic drugs. Life Sciences, 65(4): 337-53.

Doumas, B.T.; Ferry, B.W.; Sasse, E.A. and Straum, J.V. (1971): Clinica. Aplicada. Amposta. Spain. Clin. Chem., 19: 984-993.

Doumas, B.T.; Kwok-Cheung, P.P.; Perry, B.W.; Jendrzejczak, B.; McComb, R.B.; Schaffer, R. and Hause, L.L. (1985): Candidate reference method for determination of total bilirubin in serum: Development and validation. Clinical Chemistry, 31(11): 1779-1789.

Formica, J. V. and Regelson, W. (1995): Review of the biology of quercetin and related bioflavonoids. Food and Chemical Toxicology, 33(12): 106180 .

Friedewald, W.T. (1972): Determination of HDL. Clin. Chem., 18:499.

Fuhrman, B. and Aviram, M. (2001): Flavonoids protect LDL from oxidation and attenuate atherosclerosis. Current Opinion in Lipidology, 12(1): 41-8.

Gnoni, G. V.; Paglialonga, G. and Siculella, L. (2009): Quercetin inhibits fatty acid and triacylglycerol synthesis in rat-liver cells. Eur. J. Clin. Invest., 39: 761-768.

Gomal, N.J.; Azuma, K. and Van Denmark, P.J. (1949): Determination of total protein. Arch. Biochem. Biology, 88: 250-255.

Haussament, T. U. (1977): Determination of alkaline phosphatase. Clin. Chem. Acta, 35:271-273 .

Hegsted, D. M.; Mills, R. C.; Evehjem, C. A. and Hart, E.B. (1941). Choline in nutrition of chicks. J. of Biol. Chem., 138:459-470.

Henry, R. J. (1974). Clinical Chemistry Principal and Techniques. $2^{\text {nd }}$ Ed. Harper and Publisher. New York.

Hii, C. S. T. and Howell, S. L. (1985): Effects of flavonoids on insulin secretion and $45 \mathrm{Caq} 2$ handling in rat islets of Langerhans. J. Endocrinol., 107: $1-8$.

IDF (International Diabetes Federation) (2013): Diabetes Atlas, Brussels, Belgium, International Diabetes Federation, http://www.idf.org/diabetesatlas. 
Igarashi, K. and Ohmuma, M. (1995): Effects of isorhamnetin, rhamnetin, and quercetin on the concentrations of cholesterol and lipoperoxide in the serum and liver and on the blood and liver antioxidative enzyme activities of rats. Biosci. Biotechnol Biochem., 59: 595-601.

Ioku, K.; Tsushida, T.; Takei, Y.; Naktani, N. and Terao, J. (1995): Biochimica et Biophysica Acta, 1234: 99-104.

Jerine, S. P.; Shalini, M.; Giridharan, R.; Kadar, S. B.; Udhaya, B. L. and Sabina, E. P. (2020): Administration of coenzyme Q10 to a diabetic rat model: Changes in biochemical, antioxidant, and histopathological indicators. International Journal of Diabetes in Developing Countries volume 40, pages 143-152.

Jung, C. H.; Cho, I.; Ahn, J.; Jeon, T. I. and Ha, T.Y., (2013): Quercetin reduces high fat diet induced fat accumulation in the liver by regulating lipid metabolism genes. Phytotherapy Research, 27(1): 139-143.

Kamada, C.; da Silva, E. L.; Ohnishi-Kameyama, M.; Moon, J. H. and Terao, J. (2005): Attenuation of lipid peroxidation and hyperlipidemia by quercetin glucoside in the aorta of high cholesterol-fed rabbit. Free Radic Res., 39: 185-194.

Kaplan, L. A. (1984): Clinical Chemistry. The C.V. Mosby Co. St Louis. Toronto. Princeton, 1032-1036.

Kerry, N. L. and Abbey, M. (1997): Red wine and fractionated phenolic compounds prepared from red wine inhibit low density lipoprotein oxidation in vitro. Atherosclerosis, 135: 93-102.

Kleemann, R.; Verschuren, L. Morrison, M.; Zadelaar, S.; Van-Erk, M. J.; Wielinga, P. Y. and Kooistra, T. (2011): Antiinflammatory, anti proliferative and anti-atherosclerotic effects of quercetin in human in vitro and in vivo models. Atherosclerosis, 218: 44-52.

Lee, B. J.; Tseng, Y. F.; Yen, C. H. and Lin, P. T. (2013): Effects of coenzyme Q10 supplementation (300 mg/day) on antioxidation and antiinflammation in coronary artery disease patients during statins therapy: A randomized, placebo-controlled trial. Nutr J.,12(1):142.

Lee, B.; Lin, Y.; Huang, Y.; Ko, Y.; Hsia, S.; Lin, P. (2012): The relationship between Coenzyme Q10, oxidative stress, and antioxidant enzymes activities and coronary artery disease. Sci. World J., 2012: 1-8. doi:10.1100/2012/792756.

Lee, K. H.; Park, E.; Lee, H. J.; Kim, M. O.; Cha, Y. J.; Kim, J. M.; Lee, H. and Shin, M. J. (2011): Effects of daily quercetin-rich supplementation on cardiometabolic risks in male smokers. Nutr. Res. Pract., 5: 28-33.

Littarru, G. P. and Langsjoen, P. (2007): Coenzyme Q10 and statins: biochemical and clinical 
implications. Mitochondrion. 2007;7(Suppl):S168-S174.

doi: 10.1016/j.mito.2007.03.002.

Littarru, G. P.; Tiano, L.; Belardinelli, R. and Watts, G. F. (2011): Coenzyme Q10, endothelial function, and cardiovascular disease. Biofactors., 37(5):366-73.

Mariee, A. D.; Abd-Allah, G. M. and El-Beshbishy, H. A. (2012): Protective effect of dietary flavonoid quercetin against lipemic-oxidative hepatic injury in hypercholesterolemic rats. Pharm Biol., 50(8):1019-25. doi: 10.3109/13880209.2012.655424.

Martelli, A.; Testai, L.; Colletti, A. and Cicero, A.F. (2020): Coenzyme Q10: Clinical applications in cardiovascular diseases. Antioxidants. 9: 341

Matyjaszek-Matuszek, B.; Pyzik, A.; Nowakowski, A. and Jarosz, M. J. (2013): Diagnostic methods of TSH in thyroid screening tests. Ann Agric Environ Med.; 20(4):731-735.

Nakagawa, S.; Nakayama, H. Sasaki, T.; Yoshino, K. and Yu, Y. Y. (1973): A simple method for the determination of serum free insulin levels in insulin-treated patients. J. of Diabetes. 22(8):590-600. doi: 10.2337/diab.22.8.590.

Nauck, M.; Warnick, G. R. and Rifai, N. (2002): Methods for Measurement of LDL-Cholesterol: A Critical Assessment of Direct Measurement by Homogeneous Assays versus Calculation. Clinical Chemistry, 48 (2): 236-254.

Novoselova, E. G.; Lunin, S. M.; Novoselova, T. V.; Khrenov, M. O.; Glushkova, O. V.; Avkhacheva, N. V.; Safronova, V. G. and Fesenko, E. E. (2009): Naturally occurring antioxidant nutrients reduce inflammatory response in mice. Eur J Pharmacol. 615(1-3):234-40. doi: 10.1016/j.ejphar.2009.05.004.

Nuraliev, I. N. and Avezov, G. A. (1992): The efficacy of quercetin in alloxan diabetes. Eks. Klin. Farmakol., 55: 42-44.

Pattn, C. J. and Croush, S. R. (1977): Enzymatic Determination of Urea. J. of Anal. Chem., (230): 464-469.

Peter, J. S.; Shalini, M.; Giridharan, R.; Basha, K. S.; Lavinya, U. B. and Prince, S. E. (2019): Administration of coenzyme Q10 to a diabetic rat model: changes in biochemical, antioxidant, and histopathological indicators. International Journal of Diabetes in Developing Countries; 40 (1): 143-152. 
Quinzii, C. M.; Di-Mauro, S. and Hirano, M. (2007): Human coenzyme Q10 deficiency. Neurochem Res. 32: 723-727.doi: 10.1007/s11064-006-9190$\mathrm{z}$.

Rayalam, S.; Della-Fera, M. A. and Baile, C. A. (2008): Phytochemicals and regulation of the adipocyte life cycle. Journal of Nutritional Biochemistry, 19(11): 717-26.

Reitman, S. and Frankel, S. (1957). Determination of serum glutamic oxaloacetic transaminase and serum glutamic pyruvic transaminase. Am. J. Chem. Path., 28: 56-68.

Safari, M. R. and Sheikh, N. (2003): Effects of flavonoids on the susceptibility of low-density lipoprotein to oxidative modification. Prostaglandins Leukotrienes and Essential Fatty Acids, 69(1): 73-7.

Salvamani, S.; Gunasekaran, B.; Shaharuddin, N. A.; Ahmad, S. A. and Shukor, M. Y. A. (2014): Antiartherosclerotic. effects of plant flavonoids. Journal of Biomedicine and Biotechnology, (7):480258 doi: $10.1155 / 2014 / 480258$.

Samanta, S. L.; Tushar, E.; Jubaida, K. R.; Nowreen, I. C.; Manoneeta, S.; Preeti, J.; Tabinda, I.; Zarin, T. G.; Manik, C. S. and Hasan, M. R. (2021): Coenzyme Q10 and silymarin reduce $\mathrm{CCl} 4$ induced oxidative stress and liver and kidney injury in ovariectomized rats-implications for protective therapy in chronic liver and kidney diseases. J. of Pathophysiology, 28(1): 50-63. https://doi.org/10.3390/pathophysiology28010005

Schultz, A.(1984): Uric acid determination. J. Clin Chem. Mosby Co. St. Louis Toronto. Princeton, 1261, 1266 and 418.

Singh, R.B.; Kumar, A.; Niaz, M.A.; Singh, R.G. and Gujrati, S.; Singh, V.P. (2000): Randomized double-blind placebo-controlled trial of CoQ10 in chronic renal failure. J. Nutr. Environ. Med., 10: 281-288.

Soh, S. and Aw, T. (2019): Laboratory testing in thyroid conditions - pitfalls and clinical utility. Ann. Lab. Med. 39(1): 3-14. doi: 10.3343/alm.2019.39.1.3.

Sohal, R. S.; Kamzalov, S.; Sumien, N.; Ferguson, M.; Rebrin, H. K. R. and Forster, M. J. (2006): Effect of coenzyme Q10 intake on endogenous coenzyme Q content, mitochondrial electron transport chain, antioxidative defenses, and life span of mice. Free Radic. Biol. Med., 40(3): 480-7.

Song, M. H.; Kim, H. N.; Lim, Y. and Jang, I. S.(2017): Effects of coenzyme Q10 on the antioxidant system in SD rats exposed to lipopolysaccharideinduced toxicity. Lab. Anim. Res., 33(1): 24-31.

SPSS (2008): Statistical Package for Social Science, Computer Software, IBM, SPSS Ver. 16.0 in 2008. SPSS Company, London, UK. 
Sreekutty, M. S. and Mini, S. (2016): Ensete superbum ameliorates renal dysfunction in experimental diabetes mellitus. Iran J Basic Med Sci., 19(1): 111-118.

Oyedemi, S. O.; Nwaogu, G.; Chukwuma, C. I.; Adeyemi, O. T.; Matsabisa, M. G.; Swain, S. S.; Aiyegoro, O. A. (2020): Quercetin modulates hyperglycemia by improving the pancreatic antioxidant status and enzymes activities linked with glucose metabolism in type 2 diabetes model of rats: In silico studies of molecular interaction of quercetin with hexokinase and catalase. Journal of Food Biochemistry. 44 (2). https://doi.org/10.1111/jfbc. 13127

Turunen, M.; Olsson, J. and Dallner, G. (2004) Metabolism and function of coenzyme Q. Biochimica et Biophysica Acta (BBA)-Biomembr.1660 (1):171-99.

Tušimová, E.; Packová, D.; Kováčik, A.; Ondruška, L.; Jurčík, R. and Kolesárová, A. (2017): Possible stimulatory effect of quercetin on secretion of selected pituitary hormones. Animal Science and Biotechnologies. 50 (1): 135-139.

Vessal, M.; Hemmati, M. and Vasei, M. (2003): Antidiabetic effects of quercetin in streptozocin induced diabetic rats. Comparative Biochemistry and Physiology. Toxicology \& Pharmacology, 135: 357-64.

WHO (World Health Organization) (2016): Global Status Report Noncommunicable Diseases, World Health Organization, Geneva (Switzerland), 2016.

Xu, Z.; Huo, J.; Ding, X.; Yang, M.; Li, L. and Dai, J. et al. (2017): Coenzyme q10 improves lipid metabolism and ameliorates obesity by regulating CaMKII-mediated PDE4 inhibition. Sci Rep. 7(1): 8253-8264.

Yang, D. K. and Kang, H. S. (2018): Anti-diabetic effect of co-treatment with quercetin and resveratrol in streptozotocin-1nduced diabetic rats. Biomolecules \& Therapeutics (Seoul), 26(2): 130-138

Yang, H.; Song, Y.; Liang, Y. and Li, R. (2018): Quercetin Treatment Improves Renal Function and Protects the Kidney in a Rat Model of Adenine-Induced Chronic Kidney Disease. J. Med. Sci. Monit., 24: 47604766. doi: 10.12659/MSM.909259.

Young, D. and Pestaner, L. (1975). Determination of triglycerides. Germany. J. of Clin. Chem., 21: 25. 


\section{ملخص البحث}

دراسة التأثيرات المقارنة المضادة لمرض السكري لمرافق الإنزيم كيو · 1 والكويرستين في الفئران

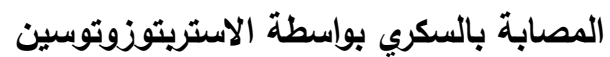

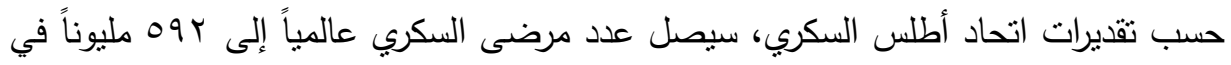

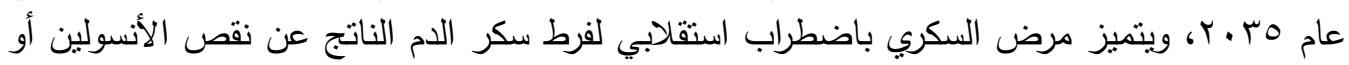

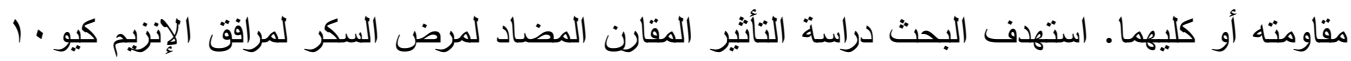

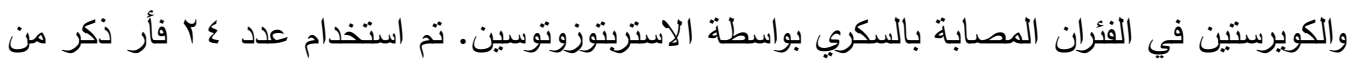

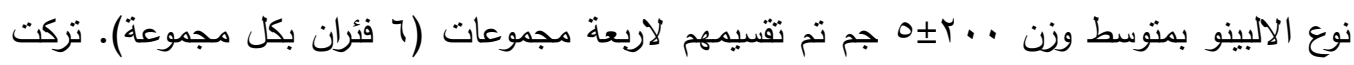

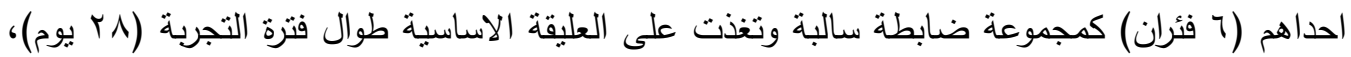

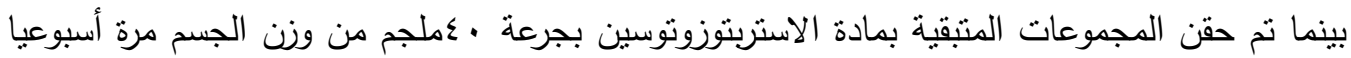

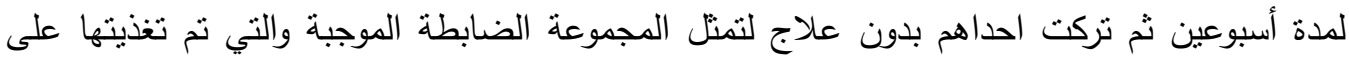

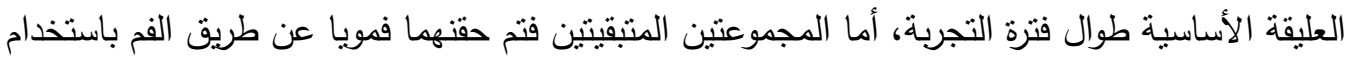
مرافق الانزيم كيو • (1 والكويرستين عند جرعة . . 1 ملجم من وزن الجسم عن طريق الحقن الفموي لكل

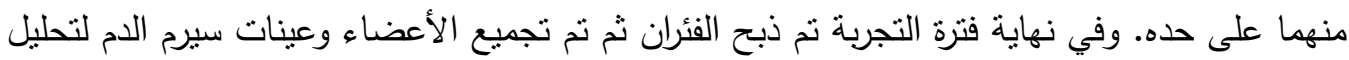

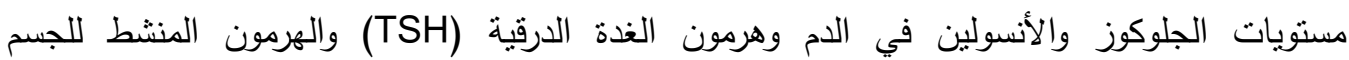

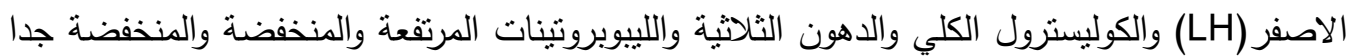

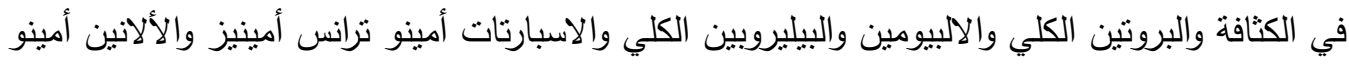

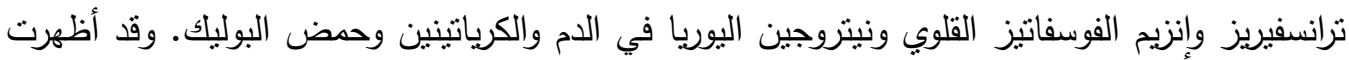

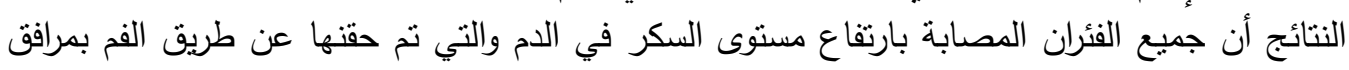

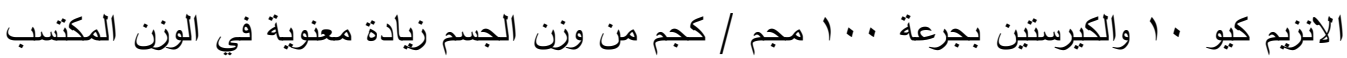

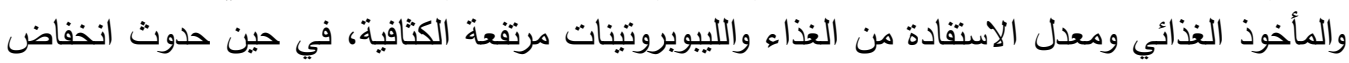

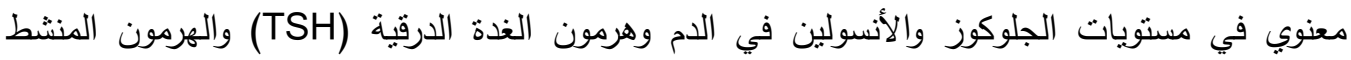

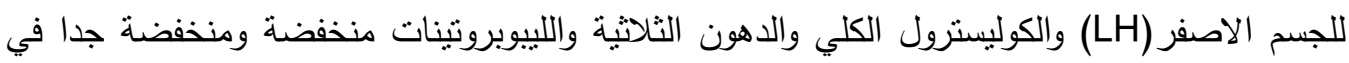

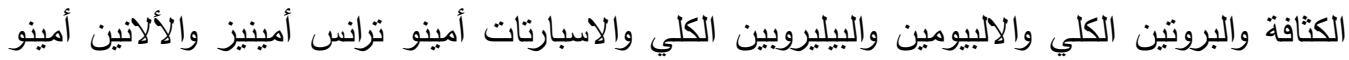

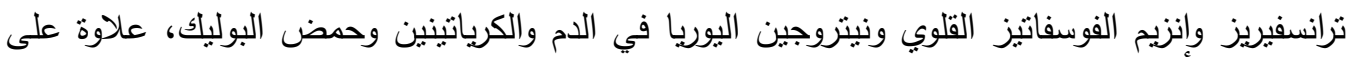

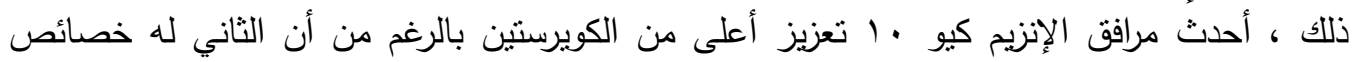

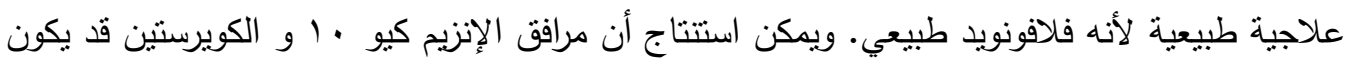

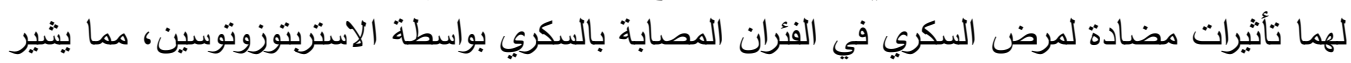

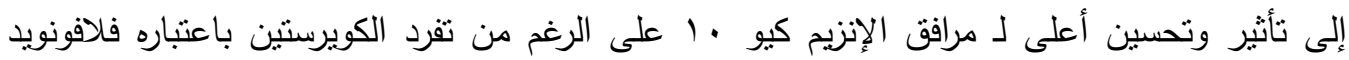
الكلمات المفتاحية: مرافق الإنزيم كيو •ا، الكويرستين، الاستربتوزوتوسين، الفئران المصابة بداء

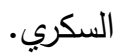

